\title{
Full Translation of Fifty Days to Encounter the Five Spirits
}

Wuyin 戊寅 Day. For those afflicted on this day, the ghost is surnamed Yan 閆, named Zhao 啔. It has one body with four arms, holding a large ax. When it encounters humans it begins chopping. It causes the person to be unable to raise their four limbs, to feel cold and suddenly hot. This ghost is setting in the northeast direction on something metal. It will be good if it departs.

Wuyinri bingzhedezhi, qi gui xing Yan ming Zhao. Yishen sishou zhidafu. Fengren jikan. Lingren sizhi buju, huhan zhare. Gui zai dongbei tieqi shang zuo. Quzhi zeji.

戊寅日病者得之, 其鬼姓閆名䒫。一身四手執大斧。逢人即砍。令人四肢 不舉, 忽寒乍熱。鬼在東北鐵器上坐。去之則吉。 $(\text { p. } 1)^{1}$

Yimao 乙卯 Day. The person afflicted on this day is by the ghost surnamed Gu 顧 or $\mathrm{Hu}$ 胡. Its body is like a wild beast searching for someone in the distance and acts like it wants to eat their heart and liver. It causes people to get a headache and fever, and the eyelids to swell and the stomach becomes hot. The ghost is in the south or northwest sitting on a rock or lying down to sleep. Good to have it gone.

1 All the descriptions listed below enumerate the affliction to be experienced when one of these ghosts is encountered. Plagues, illness, and physical misfortune were regularly linked to troublesome or malicious ghosts. For some scholarly comments on this situation with plague gods, see Paul R. Katz, "The Pacification of Plagues: A Chinese Rite of Affliction," Journal of Ritual Studies, 9, no. 1 (Winter 1995); idem, "Divine Justice in Late Imperial China," 2: 872-873. Another listing of the ghosts that afflict people, calculated for a thirty-day period, is given in Household Almanac [Jujia biyong 居家必用], a chaoben of 157 pages that I bought in Beijing in June 2010. This lists the ghosts by day, gives the surname of the ghost, location in the home where the ghost can be found. The date written in the booklet is 1935 (p. 155), but the original date of the manuscript dates from the Qing dynasty. It is intended for residents of: Great Qing, Shandong Laizhou fu, Gaomi County, Zemin xiang, Dianxi she, Immortal Li Village [DaQingguo, Shandong, Laizhoufu, Gaomixian, Zeminxiang, Dianxishe, Lixianzhuang 大清 國, 山東, 萊州府, 高密縣, 澤民鄉, 店西社, 李仙庒]. Gaomi has achieved some prominence as the home of the 2012 Nobel Prize winner for literature Mo Yan 莫言. Gaomi is 41 miles $(66 \mathrm{~km})$ from the port of Qingdao 青島. This section of the manuscript (pp. 139$150)$ is titled "List of Sick Days" [Fabingshu 法病書]. The book is $7 \frac{3 / 4}{4}$ in $(19.68 \mathrm{~cm}) \mathrm{h} \times 5$ in $(12.7 \mathrm{~cm})$ w. The importance of having the ghosts named is referred to in Lin, Materializing Magic Power, 35 .

(C) RONALD SULESKI, 2018 | DOI:10.1163/9789004361034_016

This is an open access chapter distributed under the terms of the prevailing CC-BY-NC License at the time of publication. 
Yimaori bingzhedezhi, qi gui xing Gu, Hu. Xing ru mengshou, yuanshexunren, renyaochi xingan. Lingren toutong xinteng gunei, yanbaozhang, faganre. Gui zai zhengnan, xibei shitou shang zuo, daoze zuowo. Quzhi zeji.

乙卯日病者得之, 其鬼姓顧, 胡。形如猛獸, 遠舍尋人, 人要吃心肝。令 人頭痛心疼脵內, 眼胞脹, 發肝熱。鬼在正南, 西北石頭上坐, 倒側坐臥。 去之則吉。(p. 1)

Gengchen 庚辰 Day. The person afflicted on this day is by the ghost surnamed Lu 魯. Its body is thin and frail, as if it were a sick person. It gets up and falls down headfirst. It causes the person's body to feel heavy, to speak strangely in nonsense syllables. The ghost is in the southeast wall, roaring and loudly calling out. Best to get it gone.

Gengchenribingzhedezhi, qi guixing Lu. Shenti shouruo, xing ru bingrong qizuo diandao. Lingren shenti rongzhong, huyanluanyu. Gui zai dongnan qianghounei, huhuan. Quzhi zeji.

庚辰日病者得之, 其鬼姓魯。身體瘦弱形如病容, 起坐顛倒。令人身體容 重, 胡言亂語。鬼在東南墻吼內, 呼喚。去之則吉。(pp. 1 and 2)

Xinsi 辛巳 Day. The person afflicted on this day is by a ghost surnamed Lin 林. Its body is like that of a soft maiden, tarted up like a prostitute. It causes the person's body to become heavy, flashing hot and cold and not at ease. The ghost is in the southeast setting on a round grain basket. Best to have it gone.

Xinxiri bingzhedezhi, qi gui xing Lin. Xingru jiaonv, meimao fengliu. Lingren shenti chenzhong. Hanre bu'an. Gui zai dongnanqi shang zuo. Quzhi zeji.

辛巳日病者得之, 其鬼姓林。形如嬌女, 美貌風流。令人身體沉重。寒熱 不安。鬼在東南器上坐。去之則吉。(p. 2)

Renwu 王午 Day. The person afflicted this day is bothered by a ghost surnamed Ma 馬. Its shape is round like a threshing stone spinning in no fixed spot. It makes people lose their appetite. Their four extremities become heavy. The ghost is in the southeast crack of the wall. Paste over the opening and that will be good.

Renwuri bingzhedezhi, qi guixing Ma. Xing ru lux. ${ }^{2}$ Zhuandong buding. Lingren yinshi bugan, sizhi rongzhong. Gui zai dongnan bishang fengnei. Zhihuzhi, zeji.

王午日病者得之, 其鬼姓馬。形如碌口轉動不定。令人飲食不甘, 四肢容 重。鬼在東南壁上縫內。紙糊之, 則吉。(p. 2)

$2 \quad L u$ written with the radical for stone shi 石 and you 由. The following character is undetermined and therefore represented with an $\mathrm{x}$. 
Guiwe $i$ 癸未 Day. The person afflicted on this day is bothered by a ghost surnamed Zhao 趙 and named Xiao 小. Its appearance is that both eyes are blind and it cannot see. It causes the body to become weak and achy, speak incoherently and walk about randomly. The ghost is hiding in an old shoe in the southeast. It will be good to have it leave the shoe.

Guiweiri bingzhedezhi, qi gui xing Zhao, ming Xiao. Xing ru rongshuangxia kebujian. Lingren bianshen tongteng luanyan, xing buding. Gui zai dongnan jiuxiezhong cangzhi. Quxie zeji.

癸未日病者得之, 其鬼姓趙, 名小。形如容隻瞎客不見。令人遍身痛疼亂 言, 行不定。鬼在東南舊鞋中藏之。去鞋則吉。(p. 3)

Jiashen 甲申 Day. The person afflicted on this day is bothered by a ghost surnamed Sui 隨 or Lu 逐. Its shape is like a centipede that wants to eat people's brains. It causes people to get a headache and the four limbs have no strength. It causes the brain to become absent-minded. The ghost is on the spike sticking out of the brick wall, crying. It will be good to get him off the spike.

Jiashenri bingzhedezhi, qi gui xing Sui, Lu. Xing ru youyan, yaochi rennaozi. Lingren touteng, sizhi wuli, xinnei huanghu. Gui zai dongnan qiangjuezi shang, zeku. Qu juezi ziji.

甲申日病者得之, 其鬼姓隨, 逯。形如蚰蜒, 要吃人腦子。令人頭疼, 四肢無力, 心內恍惚。鬼在東南墻橛子上, 則哭。去橛子則吉。(p.3)

Yiyou 乙酉 Day. The person afflicted on this day is bothered by a ghost surnamed $\mathrm{He}$ 赫, or Gao 高. Its shape is like the claw of an oriole. It causes the four limbs to become heavy, and the brain to become depressed. The ghost is on the eastern wall [qiang 墻, a wall around the property] or western wall [ $b i$ 壁, a flat side of a wall], sitting on the lip of a gourd. [The original author wrote this character incorrectly, transposing the gu 古 and yue 月 sections.] Have it leave, that will be good.

Yiyouri bingzhedezhi, qi gui xing He, Gao. Xing ru yingjiao. Linren sizhi chenzhong, xinnei menluan. Gui zai dongqiang, xibi shang, hulutou zuo. Quzhi zeji.

乙西日病者得之, 其鬼姓赫, 高。形如鶯腳。令人四肢沉重, 心內悶亂。 鬼在東墻, 西壁上, 葫蘆頭坐。去之則吉。(p.3)

Bingxu 丙戌 Day. The person afflicted on this day is bothered by a ghost surnamed Xuan 軒. Its shape is like a corpse lying on a bed, whimpering like a dog. Its causes people to be unable to eat or to speak, to be chilled but hot in the morning, to speak incoherently. The ghost is in the northwest sitting on a container for salt and oil. Best to have it leave.

Bingxuri bingzhedezhi, qi gui xing Gan. Xing ru sishi wochuang, quan ku. Lingren bushi buyu, fahan chao [this character was written without the water 
radical $₹$ that it ought to have] re. Kounei luanyan. Gui zai xibei yanyouqi shang zuo. Quzhi zeji.

丙戌日病者得之, 其鬼姓軒。形如死尸臥床, 犬哭。令人不食不語, 發寒 潮熱, 口內亂言。鬼在西北鹽油器上坐。去之則吉。(p. 4)

Dinghai 丁亥 Day. The person afflicted on this day is bothered by a ghost surnamed Cheng 程. Its shape is like a carp with a wide mouth to swallow humans in one gulp. It causes people to vomit. Their mouth gets dry and the tongue burns, they cannot raise their arms or legs, which keep feeling both cold and hot. The ghost is sitting on a shoe in the northwest direction. Get rid of the shoe and that will be good.

Dinghairi bingzhedezhi, qi gui xing Cheng. Xing ru liyu zhangkou tunren. Lingren outu, kougan she re, sizhibuju, hanre buzhi. Guizaixibeixie shang zuo. Quxie, zeji.

丁亥日病者得之, 其鬼姓程。形如鯉魚, 張口吞人。令人嘔吐, 口乾舌熱 四肢不舉, 寒熱不止。鬼在西北鞋上坐。去鞋則吉。(p. 4)

Wuzi 戊子 Day. The person afflicted on this day is bothered by a ghost surnamed Sun 孫. Its shape is like a large dog with a large mouth and long fangs. In its hands it holds a cudgel to frighten the family and the spirits guarding the family. It causes the marrow of the bones to ache. The ghost is sitting on top of one of the house pillars. Have him be gone and that will be good.

Wuziri bingzhedezhi, qi gui xing Sun. Xing ru daquan, jukou changya. Shouzhi gunbang, jingdong jiaqin zhaishen. Lingren gurou tongteng. Guizai dongbeifang jiatang zhoumu shang zuo. Quzhi, zeji.

戊子日病者得之, 其鬼姓孫。形如大犬, 巨口長牙。手執棍棒, 驚動家親 宅神。令人骨肉痛疼。鬼在東北方家堂軸木上坐。去之則吉。(p. 4)

Jichou 己丑 Day. The person afflicted on this day is bothered by a ghost surnamed $\mathrm{Fu}$ 父. Its shape is like a powerful and nimble dragon that will frighten [startle] everyone in the house. It causes people to vomit, their heart hurts and feels tight. The ghost is sitting on a water vessel. Get rid of the ghost and that will bring great good.

In addition, the person afflicted on this day can be bothered by a ghost named Lian 廉. It looks like a ghost, with three eyes, one hand and one foot, holding a large hatchet to chop people. It causes people to have a headache, the brain gets confused, and one always sleeps without waking up. The ghost is sitting in the east on base of a bamboo rod near the woven mat next to the kang [warmed sitting/sleeping area made of brick, used in northern homes]. Have it leave and that will be good. 
Jichouri bingzhedezhi, qi gui xing Fu. Xing ru jiaolong, jingdong jiaqin. Lingren outu, xinteng menluan. Gui zai shuiqi shang zuo. Quzhi daji.

Youfang bingzhedezhi, qigui xing Lian. Xing ru rong, sanyan yishou yizu, zhe dafu kanren. Lingren toutong naomen, changshui buxing. Gui zai zhugan xilian kangbian shang zuo. Quzhi zeji.

己丑日病者得之, 其鬼姓父。形如蛟龍驚動家親。令人嘔吐心疼悶亂。鬼 在水器上坐。去之大吉。

又方病者得之, 其鬼姓廉。形如容, 三眼一手一足, 折大斧砍人。令人頭 痛腦悶, 常睡不醒。鬼在竹桿席策坑邊上坐。去之則吉。(p.5)

Gengyin 庚寅 Day. The person afflicted on this day is bothered by a ghost surnamed Ming 明. Its shape is like a fox, entering the house to scare the family and do bad things. It causes people to become upset. The ghost is in the northeast direction, sitting on a beam. It is good to have it be gone.

Gengyinri bingzhedezhi, qi gui xing Ming. Xing ru huli ruzhai huren, zuoguai. Lingrenxinshen buding. Gui zai dongbeiwuliang [this character is written without the wood radical 木] tou shang zuo. Quzhi zeji.

庚寅日病者得之, 其鬼姓明。形如狐狸入宅唬人, 作怪。令人心神不定。 鬼在東北屋樑頭上坐。去之則吉。(p. 5)

Xinmao 辛印 Day. The person afflicted on this day is bothered by a ghost surnamed Zhang 張. Its shape is like a beautiful maiden weeping unceasingly. It causes people's bodies to feel heavy and they can't sit or sleep well. The ghost is in the south or the southeast sitting on a metal object. It is good to have it gone.

Xinmaori bingzhedezhi, qi gui xing Zhang. Xing ru meinv tiku buzhi. Lingren shentichenzhong, zuowo buan. Gui zaizhengnan, dongnan tieqi shang zuo. Quzhi, zeji.

辛卯日病者得之, 其鬼姓張。形如美女啼哭不止。令人身體沉重, 坐臥不 安。鬼在正南, 東南鐵器上坐。去之則吉。(p.6)

Renchen 王辰 Day. The person afflicted on this day is bothered by a ghost surnamed Shi 史, named Lai 來. Its shape is a long snake that entered the house to frighten all the family members and even the kitchen god. It causes the body to feel heavy, the four limbs have no strength, the heart is confused. The ghost is sitting on a bottle in the corner of the room howling, shaking its head and clapping its hands. Great happiness when it goes away.

Renchenri bingzhedezhi, qi gui xing Shi ming Lai. Xing ru dashe rutang jingdong jiaqin zaoshen. Lingren shenti chenzhong, sizhi wuli, xinnei huanghu. Gui zai wujiao pinghuo shang zuo, yaotou paishou. Quzhi daji. 
王辰日病者得之, 其鬼姓史, 名來。形如大蛇入堂驚動家親㿝神。令人身 體沉重, 四肢無力, 心內恍惚。鬼在屋角瓶吼上坐, 搖頭拍手。去之大吉。 (p. 6)

Guisi 癸巳 Day. The person afflicted on this day is bothered by a ghost surnamed Zong 宗 or Song 宋, and named Zhi 智. Its shape is like a dog or deer [jackal?]. It causes the limbs to feel heavy, the body aches and feels upset. The ghost is hiding behind the gate. Have it be gone, that will be good.

Guisiri bingzhedezhi, qi gui xing Zong, Song, ming Zhi.Xing ru quanlu. Lingren sizhi chenzhong, shentitongteng, huanghu buning. Guizai menhou cangzhi. Quzhi zeji.

癸巳日病者得之, 其鬼姓宗, 宋, 名智。形如犬鹿。令人四肢沉重, 身體 痛疼，恍惚不寧。鬼在門後藏之。去之則吉。(p. 6)

Jiawu 甲午 Day. The person afflicted on this day is bothered by a ghost surnamed Qin 秦. Its shape is a person wearing mourning clothes but naked underneath whose hair is disheveled and it is wailing. It causes the body to feel heavy, to have aches in the stomach, intestines and head. The ghost is hiding in a hole in the west wall. Cover it over with mud and that will be good.

Jiawuri bingzhedezhi, qiguixing Qin. Xing ruxiaofu shenshang wuyi pitou, tiku. Lingren shenti chenzhong, duchang touteng. Gui zai xiqiang juezi kunei cangzhi. Nizhizeji.

甲午日病者得之, 其鬼姓秦。形如孝服, 身上無衣披頭, 啼哭。令人身體 沉重, 肚腸頭疼。鬼在西墻橛子窟內藏之。泥之則吉。(p. 7)

Yiwei 乙未 Day. The person afflicted on this day is bothered by a ghost surnamed Huang 黄. Its shape is like a hungry fish. People feel hot and cold, they are confused and unsettled. They are agitated. The ghost is sitting on the stove pipe in the kitchen. It sits chanting to the Buddha. Have it be gone and that will be good.

Yiweiri bingzhedezhi, qiguixing Huang.Xing rueyu. Renfahan chaore huanghu buding, xinshen menluan. Gui zai jiatang xianglu shang. Zuozhi, nianfo zuofu. Quzhizeji.

乙未日病者得之其鬼姓黃。形如餓魚。人發寒潮熱恍惚不定, 心神悶亂。 鬼在家堂香爐上。坐之念佛作福。去之則吉。(p. 7)

Bingshen 丙申 Day. People afflicted on this day are bothered by a ghost surnamed $\mathrm{He}$ 何 or $\mathrm{Qu}$ 曲. Its shape is like an ape that gets up and falls down again like it was crazy. It causes people to be confused and unsettled, the body feels heavy. The ghost is hiding in a hole in the south wall wailing. Cover up the hole with mud. 
Bingshenri bingzhedezhi, qiguixing He, Qu. Xing ruyuanhou qizuo diankuang. Lingren huanghu bu'an, shenti chenzhong. Gui zai nanqiang hounei cangzhi. Ni.

丙申日病者得之, 其鬼姓何, 曲。形如猿猴起坐顛狂。令人恍惚不安, 身體沉重。鬼在南墻吼內藏之。泥。(p. 7)

Dingyou 丁酉 Day. The person afflicted on this day is bothered by a ghost surnamed Zhang 張, named Zhenqing 真青. It appears with a red face and hair; its hand holds a fire wheel. It causes people to feel uncomfortably dry and hot without sweat, with continual vomiting. The ghost is on the south wall sitting on a gourd. Best for it to be gone.

Dingyouri bingzhedezhi, qi gui xing Zhang, ming Zhenqing. Mianhongfa, shouzhi huolun. Lingren zaore wuhan, outu buzhi. Gui zai nanqiang hulu shang zuo. Quzhizeji.

丁酉日病者得之, 其鬼姓張, 名真青。面紅髪, 手執火輪。令人燥熱無 汗, 嘔吐不止。鬼在南墻葫蘆上坐。去之則吉。(p. 8)

Wuxu 戊戌 Day. The person afflicted on this day is bothered by a ghost surnamed Nie 聶. Its hand holds a bow and arrow. It causes people to have a back ache, their body feels like being crushed by a stone, they speak but no sound comes out, they shake their head and act strangely. The ghost is sitting on a tree in the north direction. Have it be gone and that will be good.

Wuxuri bingzhedezhi, qi gui xing Nie. Shouzhi gongjian. Lingren shenbei tongteng, tiru shiya, zhangkou wusheng, yaotouzuoguai. Guizaizhengbeimutou shang zuo. Quzhizeji.

戊戌日病者得之, 其鬼姓聶。手執弓箭。令人身背痛疼, 體如石壓, 張口 無聲, 搖頭作怪。鬼在正北木頭上坐。去之則吉。(p. 8)

Jihai 己亥 Day. The person afflicted on this day is bothered by a ghost surnamed $\mathrm{Wu}$ 武. Its shape is like a large soft-shelled turtle that sees people then moves away. It causes people to get diarrhea, a headache, their legs feel sore and the eyes turn black. The ghost is in the northeast direction leaping about on an oil bottle with garbled speech. Take some medicine. Have it gone, that will be good.

Jihairi bingzhedezhi, qi guixing Wu. Xing rudabie, jianren jizou. Lingren shuixie, touteng, tuisuan yanhei. Gui zai dongbei youpingyou luantiao yanyu • Chiyao. Quzhizeji.

己亥日病者得之, 其鬼姓武。形如大鱉, 見人即走。令人水瀉, 頭疼, 腿酸眼黑。鬼在東北油瓶油亂跳言語。吃藥。去之則吉。(p. 8)

Gengzi 庚子 Day. The person afflicted on this day is bothered by a ghost surnamed Qiao 喬, named Pei 裴. Its body is floating. It causes people to become confused 
and unsettled, frightened, to feel hot and cold, makes the body feel hot. The ghost is hiding inside the afflicted person's clothing. Put the clothing in a high place. Burn it and that will be good.

Gengziri bingzhedezhi, qi guixing Qiao, ming Pei. Shenti qingfu. Lingren huanghu buding, jingkong hanre. Bianshen fare. Gui zai bingren yifunei cangjiang. Yifu fangzai dashang. zhizhi, zeji.

庚子日病者得之, 其鬼姓喬, 名裴。身體輕浮。令人恍惚不定, 驚恐, 寒熱。遍身發熱。鬼在病人衣服內藏將。衣服放在大上。多之則吉。(p. 9)

Xinchou 辛丑 Day. The person afflicted on this day is bothered by a ghost surnamed Zhao 趙. Its shape is like a flying bird. It causes people's soul to fall upside down. They get a headache, the mouth is dry and the tongue is bitter, the hands feel numb or tingling, the hands and feet have no strength. The ghost is sitting on a metal object next to the afflicted person. Have it be gone, that will be good.

Xinchouri bingzhedezhi, qi gui xing Zhao. Xing ru feiniao. Lingren menghun, diandao, touteng, kougan shese, shouma, shouzu wuli. Gui zai bingrenshenbang teiqi shang zuo. Quzhi zeji.

辛丑日病者得之, 其鬼姓趙。形如飛鳥。令人夢魂顛倒, 頭疼, 口乾舌 渋, 手麻, 手足無力。鬼在病人身傍鐵器上坐。去之則吉。(p. 9)

Renyin 王寅 Day. The person afflicted on this day is bothered by a ghost surnamed Kong 孔, named Fu 福. Its shape is like that of a door god [guardian spirit]. It causes the body to feel heavy, the four limbs have difficulty moving, there is no appetite for food or drink. They feel as if they had been doing hard physical labor. They have a headache; the body feels cold. The ghost is sitting on a metal object on top of the gate. Have it be gone, that will be good.

Renyinri bingzhedezhi, qi gui xing Kong, ming Fu. Xing ru menshenyang. Lingren shenti chenzhong, sizhinanxing, busiyinshi, yin dongtu xiuzao dezhi. Touteng shenleng. Guizai menhu tiewu shang zuo. Quzhizeji.

王寅日病者得之, 其鬼姓孔名福。形如門神樣。令人身體沉重, 四肢難 行, 不思飲食, 因動土修造得之。頭疼, 身冷。鬼在門戶鐵物上坐。去之則 吉。(pp. 9-10)

Guimao 癸印 Day. The person afflicted on this day is bothered by a ghost surnamed Liu 劉, named Hui 輝. Its shape is that of a sick person covered with sores. It causes the body to feel heavy, to breathe with difficulty and have a dry cough; the mouth is dry, the tongue is dry. Above the bed hang a ball made of five-colored silk. The ghost will go, that will be good.

Guimaori bingzhedezhi, qi gui xing Liu ming Hui. Xing ru bingfu bianti xuechuang. Lingren shenti chenzhong, chuansou kougan shezao. Gui zai chuangshang wuse sixian daodiao. Quzhi, zeji. 
癸卯日病者得之, 其鬼姓劉名輝。形如病夫遍體血瘡。令人身體沉重, 喘 嗽 ; 口乾舌燥。鬼在床上五色絲線倒弗。去之則吉。(p.10)

Jiachen 甲辰 Day. The person afflicted on this day is bothered by a ghost surnamed Yin 尹, named Mo 莫. Its shape is like a swan or goose. It causes one to lose their appetite, to feel hot and cold and unsettled. The ghost is on the clothes hanger acting strangely. Have it gone, that will be good.

Jiachenri bingzhedezhi, qi gui xing Yin, ming Mou. Xing ru hongyan. Lingren yinshi wuwei, hanre bu'an. Guizaiyifu jiashang zuoguai. Quzhizeji.

甲辰日病者得之, 其鬼姓尹名莫。形如鴻雁。令人飲食無味, 寒熱不安。 鬼在衣服架上作怪。去之則吉。(p. 10)

Jisi 己巳 Day. The person afflicted on this day is bothered by a ghost surnamed Kong 孔, named Mo 莫. Its body is red, with a large mouth, its body is large, its hand is made into a fist to strike people. One can feel their heart burning and the stomach swelling, the person becomes disoriented. The ghost is on the top of the bed hiding in a nail hole. Plaster it over, that will be good.

Jisiribingzhedezhi, qiguixing Kong, ming Mo. Bianshen tonghong, kouda, shenguang. Shouzhi quan daren. Lingren xinre duchang, xinshen huanghu. Gui zai chuangtoushang jueziyanneicang. Zi nizhi zeji.

乙巳日病者得之, 其鬼姓孔, 名莫。遍身通紅, 口大身光。手執拳打人。 令人心熱肚腸, 心神恍惚。鬼在床頭上橛子眼內藏。子泥之則吉。(pp. 1011)

Bingwu 丙午 Day. The person afflicted on this day is bothered by a ghost surnamed Qiu 仇. Its shape is like a lion that sometimes walks and sometimes jumps. It causes a headache, a lot of sweat, the four limbs feel heavy, people cannot stand upright. The ghost is sitting on a bamboo object in the southeast direction. Have it be gone, that will be good.

Bingwuri bingzhedezhi, qigui xing Qiu. Xing ru shizi, zoutiao buding. Lingren touteng duohan, sizhi chenzhong, zhanli buzhu. Gui zai dongnan zhuqi shang zuo. Quzhi, zeji.

丙午日病者得之, 其鬼姓仇。形如獅子, 走跳不定。令人頭疼多汗, 四肢 沉重, 站立不住。鬼在東南竹器上坐。去之則吉。(p. 11)

Dingwei 丁未 Day. The person afflicted on this day is bothered by a ghost surnamed Geng 耿, named Yin 因. Its appearance is that of a beautiful woman who smiles occasionally. It causes a headache, the body to feel heavy, the mouth is bitter without a sense of taste. The ghost is hiding in the flower-patterned [colored or woman's] clothing. Have it be gone, that will be good. 
Dingweiri bingzhedezhi, qi gui xing Geng, ming Yin. Xing ru meiren shichang haoxiao. Lingren touteng shenzhong, kouku wuwei. Gui zai bingren huayang yifu neicang. Quzhizeji.

丁未日病者得之, 其鬼姓耿, 名因。形如美人時常好笑。令人頭疼身重口 苦無味。鬼在病人花樣衣服內藏。去之則吉。(p. 11)

Wushen 戊申 Day. The person afflicted on this day is bothered by a ghost surnamed Liang 梁. Its shape is that of a wheel that keeps spinning without stopping. It causes a headache, the cheeks to get red [because of fever], there is no appetite for drink or food. The ghost is hiding in the afflicted person's hair. Comb it out and the ghost will leave, that will be good.

Wushenri bingzhedezhi, qi guixing Liang. Xing ru chelun, qudong buan. Lingren touteng, saihong, busiyinshi. Gui zai bingren toufa nei cangzhi. Shuqu zeji.

戊申日病者得之其鬼姓梁。形如車輪去動不安。令人頭疼, 腮紅, 不思飲 食。鬼在病人頭髮內藏之。梳去則吉。(p.12 $)^{3}$

Jiyou Day. The person afflicted on this day is bothered by a ghost surnamed Miao 苗 or Lv 吕. Its shape is that of an orangutan or a fox [i.e., it is furry]. It acts coquettishly. It causes the body to feel hollow [light and empty] with a headache. The ghost is inside the south wall lying down, uncomfortably singing. Have it be gone, that will be good.

Jiyouri bingzhedezhi, qi gui xing Mo, Lv. Xing ru xingxing, huli meimao duojiao. Lingren shenti xuanlu, touteng huoluan. Gui zai nanfang qiangnei gangxia shichang. Quzhizeji.

己西日病者得之, 其鬼姓苗, 吕。形如猩猩, 狐狸美貌多矯。令人身體懸 盧, 頭疼霍亂。鬼在南方腔內尷下時昌。去之則吉。(p. 12)

Gengxu 庚戌 Day. The person afflicted on this day is bothered by a ghost surnamed Xian 鮮. Its shape is as a fierce tiger. It causes the fingers and feet to ache, the stomach to feel empty, the mouth is bitter with no sense of taste. The ghost is standing on the cover of the cooking pot [guo 鍋] frightening the stove god. Have it be gone, that will be good.

3 Until the end of the Qing dynasty in 1912, both men and women tended to keep their hair long. A trend toward shorter hairstyles for both men and women became more common in China in the 1930s. Hairstyles have long been a topic of interest to the Chinese, especially for children and women. Some of the popular practices still in effect in the period 1850-1950 among them are given in Shiyong Zhongguo fengsu cidian, 332-333. Much of the emphasis in premodern times was in covering the head and hair, as seen in Wan Hong 萬虹, ed., Tujie minsu Daquan 圖解民俗大全 [Collection of Popular Customs, Illustrated] (Hulunbeier: Neimenggu chubanshe, 2012), 40-44, 74-78. 
Gengxuri bingzhedezhi, qi gui xing Xian. Xing ru menghu. Lingren shouzu bingteng, fu'e, kouku wuwei. Gui zai guogai shang zhan, jingdong zaoshen bu'an. Quzhi zeji.

庚戌日病者得之, 其鬼姓鮮。形如猛虎。令人手足病疼, 腹餓, 口苦無 味。鬼在鍋蓋上站, 驚動㿝神不安。去之則吉。 $(\mathrm{pp} .12-13)^{4}$

Xinhai 辛亥 Day. The person afflicted on this day is bothered by a ghost surnamed $\mathrm{Su}$ 蘇, named Dian 顛. It has three heads and six arms. ${ }^{5}$ The person feels confused, with no strength in the four limbs, no appetite for drink or food, with violent nightmares [paimeng 拍夢; that cause the body to move, the hands to pound against the bed or to awaken the sleeper], and with wild speech. The ghost is sitting on a metal object above the bed. Have it be gone, that will be good.

Xinhairi bingzhedezhi, qi gui xing Su, ming Dian. Xing ru santou liubei. Lingren xinnei huanghu, sizhi wuli, buweiyinshi, paimeng luanyan. Guizai chuangtou tieqi shang zuo. Quzhi zeji.

辛亥日病者得之, 其鬼姓蘇, 名顛。形如三頭六背。令人心內恍惚, 四肢 無力, 不胃飲食, 拍夢亂言。鬼在床頭鐵器上坐。去之則吉。(p. 13)

Renzi 王子 Day. The person afflicted on this day is bothered by a ghost surnamed Can 參. Its shape is like a leopard, frightening everyone in the family. It causes the body to feel heavy, the legs to ache. The ghost is sitting on a vessel used for oil. Have it be gone, that will be good.

4 The stove god was symbolic of the peace, harmony, and security of the household, since one function of the stove god was to continuously provide food for the family members. Newlyweds would stop to worship before the stove god in their new home as part of their wedding ceremony. This practice is described in a chaoben I bought in Beijing in January 2015 titled Ceremonies [Liben 禮本], written by Wu Shubi 吳書壁 probably in 1945. Newlyweds stopping before the stove god is on p. 14. Ceremonies is $7^{1 / 4}$ in $(18.41 \mathrm{~cm}) \mathrm{h} \times 5^{1 / 2} \mathrm{in}(13.97 \mathrm{~cm})$ w. It has seventy pages. Women especially needed to follow strict protocols in relation to the stove god, as is explained in Ren Cheng 任騁, Zhongguojinjifengsu 中國禁忌風俗 [Chinese Common Taboos] (Zhengzhou: Henan wenyi chubanshe, 2013), 183-187. The description by the yinyang master discussed in the chaoben examined here indicates that the goblin causing trouble is upsetting the household to its very foundations. In this description, the yinyang master wrote the word gai, which means “cover" and should have been written 蓋 but was, instead, written 該 but eliminating the yan 言 radical. It is an example of a miswritten or nonstandard character.

5 The phrase "six arms" is written liubei 六背. The word means "back" and is usually pronounced bei, but in some parts of China is pronounced $b i$. It is used here to mean "shoulders," which I translate as "arms." 
Renziri bingzhedezhi, qi gui xing Can. Xing ru baozi, jingdong jiaqin. Lingren shenti chenzhong, tuiteng. Gui zai youqi shang zuo. Quzhi, zeji.

王子日病者得之, 其鬼姓參。形如豹子, 驚動家親。令人身體沉重, 腿 疼。鬼在油器上坐。去之則吉。(p.13)

Guichou 癸丑 Day. The person afflicted on this day is bothered by a ghost surnamed Yao 要. Its shape is like an earthworm. It causes both the feet and the legs to swell. It feels like bugs are crawling on the back of the head. The ghost is in the northeast direction sitting on a water vessel. Have it be gone, that will be good.

Guichouri bingzhedezhi, qi gui xing Yao. Xing ru qiuyin. Lingren zhijiao juteng, naohou chongheng. Gui zai dongbei shuiqi shang zuo. Quzhi, zeji.

癸丑日病者得之, 其鬼姓要。形如蚯蚓。令人膇腳俱疼, 腦後蟲行。鬼在 東北水器上坐。去之則吉。(p. 13)

Jiayin 甲寅 Day. The person afflicted on this day is bothered by a ghost surnamed Lu 魯. Its shape is like a dog that is on fire. It causes the body to feel like it is on fire, to feel hot and cold, with constant vomiting and no appetite. The ghost is in the southeast direction, on the wall sitting on the pan of an oil lamp hanging on the wall. Have it be gone, that will be good.

Jiayinribingzhedezhi, qi guixing Lu. Xing ru quan, bianshen sihuo. Lingren bian sihuozhi, bian sihuozhi, fachaore, outu buzhi, yinshi wuwei. Gui zai dongnanfang qiangshang gangpen shang zuo. Quzhizeji.

甲寅日病者得之, 其鬼姓魯。形如犬, 遍身似火。令人遍似火之, 遍似火 之, 發潮熱, 嘔吐不止, 飲食無味。鬼在東南方墻上釭盆上坐。去之則吉。 (p. 14) ${ }^{6}$

Yimao 乙印 Day. The person afflicted on this day is bothered by a ghost surnamed $\mathrm{Fu}$ 符 or Ren 任. Its shape is that of a toad that wants to eat people's blood. ${ }^{7}$ It causes a headache, the four limbs have no strength, one becomes disoriented. The ghost is in the southeast direction sitting on a metal implement. Have it be gone, that will be good.

6 In the chaoben translated here, the phrase "It causes the body to feel like it is on fire" [bian sihuozhi 遍似火之] appears twice in the original, but I have translated it only once. I don't know whether the copyist simply made a mistake and repeated the phrase or it was repeated to stress its strong effect on the afflicted person.

7 The frog or toad represents continuous eating. It is normally a positive symbol of always having enough food to eat. In this case, it could imply that the toad will continually drain a person's blood. 
Yimaori bingzhedezhi, qi gui xing Fu, Ren. Xing ru xiama, haochi renxue. Lingren touteng, sizhi wuli, xinshen huanghu. Gui zai dongnanfang tieqi shang zuo. Quzhizeji.

乙卯日病者得之, 其鬼姓符, 任。形如蝦蟆, 好吃人血。令人頭疼, 四肢 無力, 心神恍惚。鬼在東南方鐵器上坐。去之則吉。(p.14)

Bingchen 丙辰 Day. The person afflicted on this day is bothered by a ghost surnamed Jiang 蔣. It is shaped like a spider. ${ }^{8}$ It causes the body to feel heavy, cold and hot and unsettled, many nightmares. The ghost is sitting inside the northeast wall howling. Have it be gone, that will be good.

Bingchenri bingzhedezhi, qi gui xing Jiang. Xing ru zhizhu. Lingren shenti chenzhong, hanre buan, mengduo jianguai. Gui zai dongbei qianghounei. Quzhi zeji.

丙辰日病者得之, 其鬼姓蔣。形如蜘蛛。令人身體沉重, 寒熱不安, 夢多 見怪。鬼在東北墙吼內。去之則吉。(p. 14)

Dingsi 丁巳 Day. The person afflicted on this day is bothered by a ghost surnamed Hao 郝. Its shape is a jackal/wolf that can make the door gods and the kitchen god leave their posts. ${ }^{9}$ It causes the four limbs to feel heavy, to lose one's appetite. The ghost is in the southeast or northeast sitting on a pottery vessel. Have it be gone, that would be good.

Dingsiri bingzhedezhi, qi gui xing Hao. Xing ru chailang nenggong menshen zaoshen liwei. Lingren sizhichenzhong, busiyinshi. Guizai dongnan, bei, ciqishang zuo. Quzhizeji.

丁巳日病者得之, 其鬼姓郝。形如豹狼, 能供門神白神離位。令人四肢沉 重, 不思飲食。鬼在東南, 北, 磁器上坐。去之則吉。(p. 15)

Wuwu 戊午 Day. The person afflicted on this day is bothered by a ghost surnamed $\mathrm{Qu}$ 曲. It has a white body and a large face with white hair. It causes people to move about randomly, to speak in strange ways, often to fall down, the hands and feet have no strength. The ghost is sitting on a wooden peg behind the gate. Have it be gone, that will be good.

Wuwuribingzhedezhi, qiguixing Qu. Shenbai, mianda, baitoufa. Lingren huzou, kuangyan luanyu, shenghao daodiao, shouzu wuli. Gui zai menhou mujue shang zuo. Quzhi, zeji.

8 According to my Chinese friends, in China spiders are generally considered scary creatures.

9 This phrase "can make the door gods and the kitchen god leave their posts" [nenggong menshen zaoshen liwei 能供門神皇神離位] means it causes them to abandon their duty as guardians of the house and of the family dwelling there. 
戊午日病者得之, 其鬼姓曲。身白, 面大, 白頭髮。令人胡走, 狂言亂 語, 身好倒吊, 手足無力。鬼在門後木橛上坐。去之則吉。(p. 15)

Jiwei 已未 Day. The person afflicted on this day is bothered by a ghost surnamed Bo 薄, named Xiao 曉. It looks like a Buddhist monk with no legs or feet, it keeps vomiting unceasingly. People get chills and a fever and it is hard for them to breath. The ghost is in the southeast direction sitting on a bundle of straw. Have it be gone, that will be good.

Jiweiri bingzhedezhi, qiguixing Bo, ming Xiao.Xing ru sengren, wushouzu, outu buzhi. Lingren fahanchaore, xiongge bushun. Gui zai dongnanfang caoba shang zuo. Quzhizeji.

己未日病者得之, 其鬼姓薄, 名曉。形如僧人, 無手足, 嘔吐不止。令人 發寒潮熱, 胸膈不順。鬼在東南方草把上坐。去之則吉。(pp. 15-16)

Gengshen 庚申 Day. The person afflicted on this day is bothered by a ghost surnamed Xiao 肖, named Chang 常, it was born of a Daoist master, its hand holds a torch. It causes people to feel dry and hot without sweating, the mouth is dry, the throat feels thirsty..$^{10}$ The ghost is sitting on the colorful clothing of the afflicted person. Have it gone, that will be good.

Gengshenri bingzhedezhi, qi gui xing Xiao, ming Chang, daoshi chushen, shouzhi huoba. Lingren zaore whan, kougan houke. Gui zai bingren wuse yifu shang zuo. Quzhi, zeji.

庚申日病者得之, 其鬼姓肖, 名常, 道士出身, 手執火把。令人燥熱無 汗，口乾喉渴。鬼在病人五色衣服上坐。去之，則吉。(p. 16)

Xinyou 辛酉 Day. The person afflicted on this day is bothered by a ghost surnamed Qi 齊. Its shape is like a flying fish holding a cudgel to hit people. It causes the entire body to feel hot like burning oil. The ghost is sitting at the head of the bed on various items of clothing. Have it be gone, that will be good.

Xinyouri bingzhedezhi, qi gui xing Qi. Xing ru feiyu, chigan daren. Lingren manshen fare, rensiyoujian. Guizai chuangtouyifu huayang shang zuo. Quzhi, zeji.

辛酉日病者得之, 其鬼姓齊。形如飛魚, 持桿打人。令人滿身發熱, 人似 油煎。鬼在床頭衣服花樣上坐。去之則吉。(p. 16)

10 The text has the character 金 [ jin, gold], but most likely it should be ling [令, causes], as in the phrase lingren 令人 [to cause people to]. 